EETP Vol. 16, 2021, №. 3(61)

ISSN $1896-2327$ / e-ISSN 2353-7787

DOI: $10.35765 /$ eetp.2021.1661.08

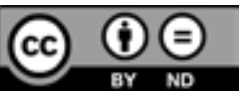

Submitted: 26.04 .2021

Accepted: 21.07.2021

Suggested citation: Szczotka M., Szewczuk K. (2021). Students of teacher training programs and their views on STEM: A focus interview, "Elementary Education in Theory and Practice", vol. 16, no. 3(61), pp. 115-137. DOl: 10.35765/eetp.2021.1661.08

Martyna Szczotka

ORCID: 0000-0003-0302-2961

Jesuit University Ignatianum in Krakow

Katarzyna Szewczuk

ORCID: 0000-0003-1914-6600

Jesuit University Ignatianum in Krakow

\title{
Students of Teacher Training Programs and Their Views on STEM: A Focus Interview
}

\author{
Studenci kierunków nauczycielskich i ich opinie na \\ temat STEM - wywiad fokusowy
}

\section{KEYWORDS ABSTRACT}

STEM, education, preschool, pedagogy students, kitchen as a laboratory,

KLab4Kids
This paper presents the outcomes of a pilot study conducted with a group of students pursuing teacher training programs as part of the international research project called "Kitchen Lab for Kids" delivered under the "Erasmus+; Key Action 2" scheme. The aim of the research was to find out about students' opinions on STEM education, including the determination of the level of their knowledge about this trend. In this context, particular attention was paid to issues related to the goals of STEM education, problems and challenges that they may generate, as well as the needs (organizational conditions) necessary to implement this type of activity. The respondents also had the opportunity to present their own experiences in organizing and conducting STEM classes. The research was carried out with the use of the qualitative methods, where the basic research method

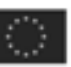 Erasmus+}

The article prepared with financial support of EU Erasmus+ programme. The European Commission's support for the production of this publication does not constitute an endorsement of the contents, which reflect the views only of the authors, and the Commission cannot be held responsible for any use which may be made of the information contained therein. 
was focus interview. The research group consisted of 8 students of teaching faculties, mainly pre-school and early school education. The selection of research units was purposeful. The conducted qualitative analysis of the material collected during the focus interview showed that STEM education is still a novelty among students of teaching faculties. Future teachers have little experience in the implementation of activities taking into account the STEM model, but it should be expected that the coming years will result in a number of changes and activities in this area.

\section{SŁOWA KLUCZE ABSTRAKT}

STEM, edukacja, Niniejszy artykuł prezentuje wyniki badań pilotażowych przeprowaprzedszkole, dzonych ze studentami kierunków nauczycielskich w ramach mięstudenci dzynarodowego projektu badawczego „Kitchen Lab for Kids”, reapedagogiki, kuchnia lizowanego w ramach programu „Erasmus+; Key Action 2”. Celem jako laboratorium, prowadzonych badań było poznanie opinii studentów na temat eduKLab4Kids kacji STEM, w tym także określenie poziomu ich wiedzy dotyczącej tego nurtu. W tym kontekście zwrócono szczególną uwagę na zagadnienia odnoszące się do celów edukacji STEM, problemów i wyzwań, jakie mogą generować, a także potrzeb (warunków organizacyjnych) niezbędnych do realizacji tego typu aktywności. Osoby badane miały również możliwość przedstawienia własnych doświadczeń w zakresie organizowania i prowadzenia STEM-owych zajęć. Badania prowadzone były w nurcie jakościowym, w którym podstawową metodą badawczą był wywiad fokusowy. Grupę badawczą stanowiło 8 studentów kierunków nauczycielskich, głównie pedagogiki przedszkolnej i edukacji wczesnoszkolnej. Dobór jednostek do badań był celowy. Przeprowadzona analiza jakościowa materiału zebranego podczas wywiadu fokusowego wskazała, że edukacja STEM to wciąż nowość wśród studentów kierunków nauczycielskich. Przyszli nauczyciele posiadają niewielkie doświadczenie w zakresie realizacji zajęć uwzględniających model STEM, ale należy się spodziewać, że najbliższe lata zaowocują szeregiem zmian i działań w tym zakresie.

\section{The Importance of STEM Education}

The concept of education based on STEM emerged relatively recently—at the end of the $20^{\text {th }}$ - and the beginning of the $21^{\text {st }}$ century. The idea encompassed both a domain area as well as teaching curricula in the following disciplines: science, technology, engineering, and mathematics. A report called: Science, Technology, Engineering, and Mathematics (STEM) Education: A Primer provides a broader perspective on STEM, 
whereby it is interpreted as "teaching and learning in the fields of science, technology, engineering, and mathematics. It typically includes educational activities across all grade levels-from pre-school to post-doctorate-in both formal (e.g., classrooms) and informal (e.g., afterschool programs) settings" (Gonzalez, Kuenzi 2012: 1). This definition clearly emphasizes understanding STEM as an element of life-long and multi-contextual educational process.

The emergence and the widespread adoption of the idea has been also connected with the inclusion into the educational offering of the requirements and standards typical of the $21^{\text {st }}$ century as well as the need to address the requirements of the everchanging labor market. This could be done as the concept of STEM proves successful in education at all levels and with all learners. As the practical experience shows, contemporary educational systems do not concentrate enough on teaching children how to address real problems and-far from interdisciplinary-they get confined within the unnatural framework of standards and principles, which is what STEM aims to be an alternative to. The transition from the current, traditional teaching approach to a holistic, interdisciplinary method makes sense especially in modern times, when opportunities are as common as challenges. Therefore, it is incumbent on future generation of teachers to fine-tune the educational offering in such a way as to equip children with the skills required for living in a reality which, as of today, remains unknown to us.

The concept of STEM-based education emphasizes the importance of preparing the young generation to define and solve problems while at the same time promoting critical thinking. By asking questions, exploring and experimenting, children themselves work out solutions to various problems. STEM can be treated as an educational strategy that is in keeping with the current trend promoting interdisciplinary and lifelong learning. Notwithstanding the above, the concept is close to everyday life and its various situations and problems and it promotes the development of interests and passions already in very young children. The STEM Model boosts learners' motivation to study and promotes the feeling of agency and in doing so, helps to prepare young researchers for their future careers in exact sciences, engineering or mathematics (Plebańska, Trojańska 2018).

It should also be stressed that the disciplines covered by STEM and their integration into various projects may constitute a very interesting area of educational activity for children. When working on projects, they gradually and systematically build up and expand their knowledge and skills within the scope of a particular problem area, they acquire new experiences and at the same time explore their immediate environment.

In conclusion of this overview of STEM impact we note that it is only recently that the importance of STEM-based instruction has been duly acknowledged not only 
in later stages of education but also in pre-school and early-school periods. Greater emphasis is currently being put on familiarizing young and very young learners with science and technology and the proper development of open attitudes and natural curiosity leading to more successful exploration of the world.

\section{Application of STEM Concept in Pre-school Education}

Exploration of the environment and becoming familiar with the surrounding world are very obvious aspects of the pre-school period. Children are naturally curious; they are happy to engage and ask questions. The role of teachers, parents and caregivers is to create an environment, which will promote the development of STEM competencies in children.

At this stage of education, children are normally interested in researching the properties of items, they learn basic notions, describe how objects appear, how things work and react to various external stimuli or factors. They like to contrast and compare features, look into how simple machines work or try to build, test or experiment with them on their own. They sometimes make attempts at categorizing and measuring things, weigh them, order them according to some pre-defined criteria. Another fascinating object of investigation can be natural sciences, topics related to ecology as well as technology, including using and combining various materials for making their own constructions and set-ups. It all enables them to carry out a number of interesting projects. According to the authors of STEM Sprouts. Science, Technology, Engineering \& Maths (2013) a well-designed educational environment, which provides children with a properly selected range of educational experiences, enables them to succeed academically and ensures that the learning process is friendly for the brain. The nursery school period is also an ideal moment for the development of positive attitudes and learning skills. Making a common effort on a project prepares children for team work and assuming responsibility for the assigned tasks as it allows them to acquire and develop communication skills (STEM Sprouts. Science, Technology, Engineering \& Maths 2013).

STEM sees the role of adults as essential to its success. Parents and teachers should accompany the child in their development. This has been communicated through a set of guiding principles proposed by the authors of Early STEM Matters: Providing High-Quality STEM Experiences for All Young Learners (Early Childhood STEM Working Group 2017). According to these principles:

"1. Children need adults to develop their 'natural' STEM inclinations.

2. Representation and communication are central to STEM learning. 
3. Adults' beliefs and attitudes about STEM affect children's beliefs and attitudes about STEM.

4. STEM education is not culturally neutral" (Early Childhood STEM Working Group 2017: 7).

It is the role of teachers to encourage children to undertake the exploration of the surrounding world. Support and sustaining motivation are crucial as at this age they are too young to exercise patience when seeking answers to the questions that are posed. If the first one or two attempts at solving the problem fail, children tend to give up further efforts altogether. It is therefore important that-when confronted with such challenges - the child is accompanied by another person, who-through the actions taken - can help sustain their cognitive activity by helping for example to define the problem, direct the child towards the right answer, encourage persistence as well as supply valuable teaching aids and materials.

Another relevant question to consider are the opinions and stereotypes, still prevalent in the society, concerning some disciplines-including mathematics, technology, engineering or exact sciences in general, which are seen as determined by inborn aptitudes or gender. Such views, sustained and voiced by adults-parents or teachers-may constitute a serious obstacle affecting the child's development. A change of attitude in this respect may result in enormous benefits-it will, first and foremost, save the child from reinforcing negative and limiting attitudes and convictions. One of the paths leading to the improvement in the quality of STEM education should be proper teacher training so as to ensure that teachers are equipped with the necessary knowledge and skills as well as support in their teaching activity.

\section{Kitchen Lab for Kids: Project Description and Aims}

The international project called "Kitchen Lab for Kids" (Klab4Kids) has been developed as an Erasmus+ initiative since 2018 (http://kitchenlab4kids.eu/). The project is a joint action of five academic centers from Poland, Italy, Ireland and Spain (Jesuit University Ignatianum in Krakow, Libera Università Maria SS. Assunta, Fondazione Politecnico di Milano, Universitat Internacional de Catalunya and Dublin City University). The project is coordinated by Jesuit University Ignatianum in Krakow. The primary goal of the project is to facilitate the exchange of experiences and good practices in the scope of promoting an active learning of exact sciences in European countries. The project outcomes should also stimulate and encourage teachers to explore modern interactive methods of teaching and learning that would support STEM education provided to children aged 3-6. KLab4Kids aims to engage teachers and parents in assisting young children in integrating knowledge from various areas 
related to STEM. Kitchen is perceived as a creative space where children can undertake their first research and conduct their own experiments. The kitchen space may become a home-lab, in which children may be introduced to the world of science and knowledge in an interesting and accessible manner. The project has been designed to combine activities performed in the kitchen, including preparation of meals, cooking and exploring various alimentary products with the acquisition of scientific knowledge. Alimentary products used for cooking as well as technological processes and physical phenomena taking place while performing various kitchen tasks are seen as objects of research and children's analyses. Also, one of the project aims has been defined as raising children's awareness of hazards which they can encounter in the kitchen environment.

The project is predominantly addressed to pre-school teachers and students of teacher training programs as well as parents of pre-school age children. The outcomes of the KLab4Kids project are expected to include diagnosis and description of teachers' needs in the scope of STEM education in participating countries as well as the development of a teaching set dedicated specifically to the needs of educational work with children both in the nursery class as well as at home. The project also aims to create a KLab4Kids community of practitioners that would address aspects of STEM methodology in pre-school education as well as evaluate the materials collected. Teachers will not only be able to take advantage of a ready-to-use set of tools and documents, or get inspired by the ideas for class scenarios and descriptions of good practice but also exchange their own experiences related to the implementation of STEM.

\section{Methodology}

\section{Research Goal and Questions}

This paper provides an overview of a study which constituted one of the initial stages of the "Kitchen Lab for Kids" project and offered a preliminary diagnosis of the knowledge of STEM among students in teacher training programs.

The aim of the study was to recognize the students' opinions on STEM education. Specific problems have been formulated as follows:

What is the level of knowledge about STEM learning among students of teacher training programs?

- What are students' attitudes towards classes incorporating elements of STEM learning?

- What are, in students' opinion, aims of classes delivered in line with STEM principles? 
- What are students' personal experiences with regard to class arrangements promoting the development of STEM skills?

- What problems (and challenges) can be generated by this type of classes?

- What is needed for effective provision of classes developing STEM competencies?

\section{Method}

The main research method applied for the purpose of the study was focus group, whose aim was a group discission held in parallel with all involved persons taking part in the session (face-to-face focus). The moderator and students of teacher training programs were concentrated on the analysis of one specific problem, which in this case was STEM. The discussion was based on a protocol developed prior to the session, which covered: screening of two films, questions and answers, presentation of the definition of STEM and final questions.

\section{Study subjects}

The study involved students of teacher training programs, mainly in preschool teaching and early school education. The focus group interview was conducted in a small (8 persons) non-random group. Members of the group were selected based on purposive sampling according to a set of criteria predefined by the researcher and adjusted to the specific nature of the project. It was intended as an attempt at collecting empirical material to be used for developing a questionnaire necessary in the subsequent, core part of the study. While focus group interviews were held in all countries participating in the project, this paper focuses specifically on findings of the procedure conducted in Poland.

\section{Procedure}

The study was conducted in December 2018 and January 2019 at Jesuit University Ignatianum in Krakow, Poland, which was the primary place of employment for the moderators. A lecture room was adapted to the needs of the procedure. The participants had been informed of the study aims and participation consent was obtained from each member of the group. Their consent was verbal and was recorded by the persons conducting the research. The study subjects had previously met as they pursued the same university program.

Group membership was relatively homogenic (Hoffman 1959: 27-32; Hoffman, Maier 1961: 401-407; Krueger, Casey 2000) which removed barriers to effective communication between the participants, increased the feeling of comfort and eventually prompted the attendees to share their views with others. The focus session took 
1.5 hours. The course of the session was recorded using a voice recorder. One moderator and her assistant were present at the session at all times. These were representatives of the Polish team taking part in the international project called "Kitchen Lab for Kids." The moderator's background was in psychology while the assistant moderator was a teacher. The presence of only one moderator in charge of a session increases the risk of deviating from the session's intended purpose as the moderator concentrates efforts on ensuring the proper atmosphere in the group and the well-being of its participants. Furthermore, the presence of two session hosts, who can take turns when moderating those areas of discussion in which they have stronger competencies, may add to the varied nature of the session and reduce the risk of the participants providing responses they believe are anticipated by the moderator (Lisek-Michalska 2013: 42). Given that the moderator's behavior may have an enormous impact on the final success of the focus group session, this must certainly not be a randomly-chosen person. Research practice has proven that a successful moderator should demonstrate specific competencies (traits), both in terms of personality as well as research and leadership. Among the personality traits the following have been identified as particularly relevant:

genuine interest in what other people think and feel, inquisitive nature and desire to seek answers to quench his/her thirst for knowledge,

- emotional expressiveness demonstrated through the (controlled) ability to show personal reactions,

spontaneity promoting high group dynamics,

sparkling personality, essential for any stimulating activity,

sense of humor without aggression or spite,

empathy which encourages proper understanding of how the study participants perceive reality,

- introspection necessary to realize and understand one's own views and emotions and-therefore-acknowledge limitations inherent in the procedure and acquire proper perspective,

ability to quickly and clearly formulate one's thoughts,

- flexibility: moderator must be able to respond quickly if any elements of the research tool are found to be ineffective,

- low level of stress in social situations,

good improvisation skills,

ability to maintain a high level of one's task orientation.

As a leader, the moderator should be able to:

- state the problem in a way that will stimulate enthusiasm and willingness to seek constructive solutions by the participants, 
- properly select information to be communicated to the participants so that it properly conveys the nature of the task without suggesting any expected responses, - control and manage group dynamics,

- cope with interruptions and silence,

- restate the group's ideas to add precision and clarity to what was contributed by the group members themselves,

ask questions to stimulate effective problem-solving,

- summarize the effects of work done by the entire group (Williams 2003: 67).

During the session the assistant handled general organization of the event (operating voice recording equipment, taking notes, offering assistance whenever complications occurred). Her presence reduced the moderator's workload, therefore creating advantageous conditions for the moderator to be exclusively focused on her core responsibility.

The focus group session had a clear structure consisting of 3 parts—each of them containing a specific type of questions. The questions asked in the early (preliminary) phase were intended as ice-breakers, increasing the feeling of comfort among the participants and setting the stage for the essential discussion. In the second part students were shown two short films (of approximately 3 minutes each), which were meant to, on the one hand, inspire the study participants to express their opinions and on the other-show the essence of STEM. The first film showed a fragment of a class with a group of preschool children experimenting with milk in what is a classic example of milk painting. The children carefully drop in some food coloring onto milk (poured into a bowl) and tap it with a toothpick or a small stick dipped in a detergent. Surprised and fascinated, they observe chemical reactions taking place in the milk, which they see as mixing of colors. The other film showed a preschool girl in the course of preparing a meal (salsa Bolognese) using Thermomix, with a little assistance from an adult person. After both films were screened, the participants were asked questions in accordance with a previously developed study protocol. Since the topics to be discussed during the session had not been disclosed to the participants (who had received only most general information on the subject matter of the session), the questions asked during the main part were specific, to the point, understandable and always referred to a single aspect only. During the last phase of the session the moderator asked questions mainly in order to establish whether everything had been said and fully and properly understood as well as to make sure that the participants did not wish to raise any additional points, make changes or supply further explanations. The three-part structure of the session was reflected in the design of the focus group protocol.

During the discussion, the invited participants enjoyed the convivial atmosphere to address the topics mentioned by the moderator, who oversaw the interview making 
sure it ran smoothly, with every participant effectively contributing to the discussion, aiming to obtain feedback on all questions contained in the interview guide. On the participants' leaving the room, the moderator together with the assistant checked the quality of the recording properly identifying the material collected and reviewed the most important ideas. Next, a transcript of the recording was made, according to the rules laid down for feedback processing.

\section{Study Findings: An Overview}

The films played to the participating audience at the beginning of the study show lively children involved in the activity. They joyfully begin the experiment, initially intrigued, then increasingly radiant and happy as they observe the outcomes of their own activity. Interestingly, the same emotional reaction was observed in the group of students watching the films. First positive comments were voiced already as the films were screened with students wondering "What will come next?" "Why did that happen?" "How is that possible?"

\section{Student attitudes towards classes incorporating elements of STEM}

The examples of STEM applications presented in the films were very enthusiastically received by the students. All members of the focus group agreed that they liked the films and found them interesting. Most of the participants commented along the lines of "I have never encountered anything like this before, I have seen it for the first time and I liked it a lot" or "If I find milk drawing interesting, then I wonder how crazy the kids are about it?" However, the students' comments referred solely to the situations observed in the films. This way of thinking proved immune to soft suggestions and questions coming from the moderator. The students participating in the discussion were not able to take a global look at the activities offered to children by nursery schools aiming to integrate various scientific disciplines (science, technology, engineering, mathematics). What is more, the students almost instantly alluded to several difficulties such classes posed. As one of the study participants remarked: "It appeals to me. Still, I believe that delivering this task in such a group can be challenging. I got the impression that the kids were very mature for their age. They could stay calm and quiet but not all children are like them." This observation opened up the discussion for some more critical opinions as on the one hand, the activities were seen as appealing yet on the other, they obviously require thorough preparation, careful design and time. Thus, the students admitted that classes like this are necessary, but not very often, "certainly, not on a daily basis, the idea is unworkable, it can't be 
done. That would simply pose too big a challenge. You could do something new like this once a month perhaps."

\section{Lesson objectives in STEM}

Students pursuing teacher training programs become familiarized with the structure of a lesson plan already from the very early stages of their university education. The ability to formulate general, specific or operational objectives will enter the repertoire of basic skills, frequently used by academic teachers as coursework assignments. It is hence a puzzling observation that the question concerning the goals of STEM education was met with grim silence from the participants of the focus study. Soft stimulation from the moderator combined with some positive encouragement and a personal example provoked only occasional responses. These have been categorized and ordered in terms of frequency (from the most frequently cited to the least communicated ones). The goals of classes that draw on the STEM Model, according to the respondents, are as follows:

- language skills: "instruction-based performance," the subjects stressed the importance of children's oral production-their comments made during the class,

- motor skills: with emphasis on manual dexterity, as communicated through the following observations: "the kid in the film added ingredients," "the kid measured out something," "that means manual practice,"

- social skills: where the respondents stressed the children's responsibility and independence (feeling adult-in the case of cooking), as well as mechanical dexterity, like in "using such a device,"

artistic and creative skills: "As I understand it, the kids focus their attention on something artistic, on performing such art-like things," "You could use it to calm kids down,"

science skills: the participating students see them in actions that involve observation as well as experiential discovering of the world, as expressed in the following comments: "the child learnt something already, he could do that...," "they learn colors, experiment with color mixing."

The study participants expressed lesson objectives by reference to skills and it was how these objectives were, in fact, understood. Also, STEM classes are perceived by the teachers-to-be as effectively promoting language or motor skills rather than cognitive ones. The latter were mentioned only by two respondents, in brief statements. 
Personal experiences of organizing STEM skills-oriented classes as reported by the participating students

As the study was carried out among students, the interviewers assumed that only a limited number of them would have any teaching experience. Even so, in the course of studies students tend to seek temporary or regular employment (e.g., babysitting), they are also offered some opportunities to organize classes during their teaching work experience and, in addition to this, classes provided by universities as part of their curriculum allow them to run activities to be later targeted at pre-school and early-school children. Notwithstanding the above, the assumptions made by the researchers proved accurate as only two subjects responded to the question relating to their personal teaching experience with STEM-based classes. One of them, employed by a Montessori nursery, observed that "some classes we do are very similar to those shown in the video. We also did classes based on color mix. There were four basic colors, which the child measured out into water with a pipette. The kid then mixed the basic colors and checked what would happen." The other person made a reference to the cooking video stating that she "had some experience with Thermomix but not in the classroom, it was more like at the kid's home. You could see the child was really fascinated by the opportunity to measure out things and then offer the final product for others to taste. It was a great fun and a good reason to feel proud." Students' responses demonstrated a clear tendency to perceive their own experiences (in the field of STEM education) in the context of the films shown to the group. The research authors hinted that the examples to be given by the students would not necessarily have to relate to the videos. Any participants who conducted classes combining at least two scientific disciplines could speak, yet the idea was not really taken up, which most likely demonstrates the subjects' very limited experience of STEM skills-oriented classes.

\section{Problems and challenges that come with STEM-based classes}

Organization of classes drawing on STEM education was considered by the subjects in terms of problems and difficulties rather than challenges leading to self-development or inspirational experience. Such attitudes were foreshadowed in the subjects' responses to the opening question that introduced the focus group interview.

Obstacles, which—according to the participants of the study—could significantly hinder more widespread introduction of STEM education in the classroom include:

- class arrangements: participants pointed to the need for small learner groups and higher number of teachers required to deliver such activities, which was expressed through responses like: "in-class performance depends on the group and the number of attending staff," "discipline is the key," "small number of children, there were 10 of them here, but if you have a class of 25 to look after, before you lay out 
the materials and props, approach every kid, explain things... that takes a lot of time," "you need to prepare the classroom in advance,"

health and safety: classes which promote children's physical involvement can, according to the study subjects, increase the risk of hazardous situations, e.g., the use of knives by the youngest ones or occurrence of food allergies and intolerance in children. Also, subjects stressed the importance of maintaining order and cleanliness after the class. One of the participants expressed this necessity in the following words: "One needs to keep things clean. During my teaching placement we had these trays with cereals, then the whole floor was strewn with the stuff. You must bear in mind the fact that if there is active physical involvement, then cleaning it all afterwards may be a must,"

- parental impact: the respondents perceived parents as a factor that may hinder pupil activity. Also, parents are regarded as those who tend to frown upon such activities being introduced to the pupils by the nursery staff. Parents do not understand the need for active exploration of the world by children, which was best expressed through comments like: "you need to spell it out to parents in advance that kids could get dirty and stained and that they should not dress them in designer labels as oil gets spilled sometimes, etc." One of the participants working for a Montessori nursery reported a frustrating situation, when "a father or mother came and complained about a 50 Euro piece of clothing getting stained." Such reproaches are a very effective deterrent for proposing various forms of activity to the youngest learners.

\section{Required arrangements for provision of classes developing STEM competencies (skills)}

According to the study subjects, arranging classes focused on developing STEM skills is very demanding (students themselves pointed out that such classes cannot be held too often), so a number of varying needs were brought up in this regard. First and foremost, the participants pointed to the organization of the class, which they expressed with the following comments: "you must properly arrange the classroom for such activities," "you should find some space as when you make such cookies, you need to bake them later" and, last but not least, financial issues: "you need money for that," "you need to make a list of necessary things, figure out what we have to buy..., then collect money from the parents." Then, the discussion took a different perspective and focused more on the involvement of external actors, with four social groups being specifically named:

- Parents: the respondents observed the need for support and contribution from the children's parents and caregivers, e.g. with regard to teaching aids, financial issues as well as cleaning. Students maintained that parents must be advised in advance 
of this type of children activity so as to mitigate possible complaints about "there not being daily worksheets completed for that day." They claim that completing worksheets is commonly "enforced," only to show that "they do something at the nursery."

- Other nursery school staff: to be understood as the involvement and support contributed to the class by all members of the nursery staff-from the principal (whose consent is required to conduct this kind of class activity) to cleaners, cooks ("you do need somewhere to bake the cookies") to teachers of other groups.

- Nursery school teachers: respondents' comments in this respect fall into two distinct groups: junior teachers and their more senior colleagues. Young practitioners were perceived by students as more willing, creative and ready to work with children using innovative methods. One participant observed that "you must feel like doing it, those younger teachers are not part of the system yet and that is why they show more enthusiasm for their work. Seniority, on the other hand, means burn-out. The 'old-style' teachers think according to patterns they picked up in the past. They stick to the system... on the other hand, they might not have the chance to learn something new. They are used to doing things their way, they have their skillset, their methods and they keep relying on those."

- Children: the stimulus for organizing classes centered around developing STEM competencies can, according to the respondents, come from the children themselves or-to be more precise-from "child involvement," "sparking true interest in such classes," "if children were happy with that-then yes..."

Other issues raised by the study participants included: lack of support, insufficient access to published papers and books as well as few sources of inspiration for this type of classes. Teacher creativity is a positive feature yet there is little information on for example "advice and tips on what can be excessively difficult for children" that is: how to adjust certain solutions to learners' age. One person brought up the problem of the national curriculum for nursery education, which, as it was stated, "does not leave too much room for the teacher and does not put any real emphasis on STEM-based classes. There is a need for greater involvement of the central authorities so that there is some space in the curriculum for free classes like these. Nursery schools must follow the national curriculum."

\section{Discussion}

The knowledge of the students participating in the study about STEM education is negligible. The term "STEM education" is unknown to them. It was only when the definition was read, and the moderator drew attention to its essential elements, that triggered a few statements among the students, such as: "we do it, but we did not 
know what it was called." This situation may be caused by the lack of systemic solutions in educating students of teaching faculties in Poland. While Rodger W. Bybee (2010: 996) drew attention to the need to develop a learning strategy focusing on STEM, this idea is still underestimated in Poland. This does not mean, however, that nothing is happening in our country in terms of STEM education. The STEM trend has been noticed; representatives of the authorities point out the need to strengthen mathematical and natural science skills, training courses for teachers and conferences promoting this model of education are initiated. By cooperating with the local community, Polish scientists carry out various projects promoting STEM education, and the database of available materials, articles and other publications in this thematic field is expanding.

\section{Conclusions}

The study findings suggest that future teachers do not possess extensive knowledge of STEM methodology. The students participating in the study reacted enthusiastically to some examples of classroom activities incorporating STEM techniques. These were found interesting, yet the organization of such classes appears to arouse concerns rather than challenges that could lead for example to career advancement. The respondents saw all difficulties as originating in the demands of class arrangements, the need to ensure safe learning and working conditions for the children as well as in the lack of understanding on the part of parents. Also, it is a disturbing fact that future teachers perceive STEM-based classes mainly in the context of developing language or motor skills rather than cognition. They do not associate STEM with an approach that would serve to build creativity and develop skills in creatively solving problems in project work, nor do they see it as promoting critical thinking or learning based on insight. In addition, they fail to notice other advantages, which include sustaining natural motivation to learn exact sciences, improving the outcomes and quality of teaching or adjusting the skills developed to the needs of the contemporary labor market. As teachers-to-be, they ought to know that they must not limit their repertoire of teaching methods to the ones which instead of stimulating free thinking and freeing up the child's creative potential tend to encourage predominantly passive attitudes. Student experience of conducting classes geared to STEM skills development is limited. Obviously, lack of methodology handbooks or school curricula centered on STEM may impede provision of such classes in a nursery school. However, they must remember that the modern world is changing dramatically. It requires that teachers, including those involved in pre-school education, adjust their educational offering to the standards of the $21^{\text {st }}$ century. STEM Education is the response to 
the neurobiological foundations of the educational process of a young person and thus becomes an effective means to develop a set of competencies for a fulfilling and rewarding life in the future.

\section{Bibliography}

Bybee R.W. (2010). What is STEM education?, "Science", vol. 329, no. 5995, p. 996. DOI: $10.1126 /$ science.1194998.

Early Childhood STEM Working Group (2017). Early STEM Matters: Providing High-Quality STEM Experiences for All Young Learners: A Policy Report by the Early Childhood STEM Working Group, http://d3lwefg3pyezlb.cloudfront.net/docs/Early_STEM_ Matters_FINAL.pdf (accessed: 01.12.2019).

Gonzalez H.B., Kuenzi J.J. (2012). Science, Technology, Engineering, and Mathematics (STEM) Education: A Primer, http://www.stemedcoalition.org/wp-content/uploads/2010/05/STEM-Education-Primer.pdf (accessed: 01.12.2019).

Hoffman R. (1959). Homogeneity of member personality and its effect on group problemsolving, "Journal of Abnormal and Social Psychology", vol. 58, no. 1, pp. 27-32.

Hoffman R., Maier N.R.F. (1961). Quality and acceptance of problem solutions by members of homogeneous and heterogenous groups, "Journal of Abnormal and Social Psychology", vol. 62, no. 2, pp. 401-407.

Krueger R.A., Casey M.A. (2000). Focus groups: A practical guide for applied research, Thousand Oaks (CA): Sage Publications.

Lisek-Michalska J. (2013). Badania fokusowe. Problemy metodologiczne i etyczne, Łódź: Wydawnictwo Uniwersytetu Łódzkiego.

Plebańska M., Trojańska K. (2018). Steam Lessons, Warszawa: Elitera.

STEM Sprouts. Science, Technology, Engineering \& Maths: Teaching Guide. (2013), https:// www.bostonchildrensmuseum.org/sites/default/files/pdfs/STEMGuide.pdf (accessed: 07.12.2019).

Williams M. (2003). Making sense of social research, Thousand Oaks (CA): Sage Publications. 


\section{APPENDIX}

\section{Focus group protocol developed for a study into STEM Education involving students of teacher training programmes}

\section{Introductory phase}

This part of the study is intended as an ice-breaker for creating more friendly and informal atmosphere. It aims to reduce the stress level that may result from the participants facing a new, unknown situation. The moderator seeks to create an atmosphere of trust and ensure that the participants feel comfortable and secure.

1. Participants are welcomed; facilitators thank them for accepting the invitation to take part in the study and turning up at the focus meeting.

2. Moderator and her assistant introduce themselves stating names and the place of employment and then briefly outline information on project participation.

3. Participants get to know each other. Self-presentation includes stating one's name and interests. The participants are then asked to prepare name cards.

Assistant moderator hands out small cards asking the participants to write their names on them (in block capitals). This way name cards are created to facilitate addressing each other during the discussion. Name cards should be pinned to clothes worn by the focus group members or placed in front of a person so that others can clearly see them.

4. Topic and purpose of the meeting are stated. The moderator briefly outlines the "Kitchen Lab 4 Kids" project encouraging active participation in the future learning community and introduces the topic and purpose of the meeting.

5. Rules of participation in the discussion are laid down. The moderator states the rules of discussion, emphasising politeness, respect for other members of the group, patience and the need to refrain from interrupting interlocutors while they present their opinions. The moderator assures students taking part in the study of its anonymity and the confidentiality of any collected data. It is explicitly guaranteed that responses elicited during the interview will be analysed and utilised exclusively for the purpose of the project. Towards the end of this part of the introduction the moderator specifies the expected length of the meeting 
and makes sure that all the participants have been comprehensively informed about the session.

6. Participants are informed about the session being recorded. The moderator informs the participants about the discussion being recorded by means of a voice recorder and then ensures that all attendees give their verbal consent to their taking part in the interview and their opinions being recorded. Participants express their consent orally.

\section{Main phase}

This part of the study aims to collect information from group members, which is the main reason for the meeting. The moderator is an important figure here as she monitors rules of conduct during the discussion and makes sure that all participants are given equal chance to voice their opinions. The moderator is also responsible for feedback, understood as a clear and unambiguous explanation and justification of the expressed views.

\section{Film screenings}

The moderator informs the participants that they will be shown two short films. They are encouraged to watch attentively but also to voice their opinions while watching. Films screened prior to the discussion were short (approximately 3 minutes each) and were meant to inspire students to speak freely as well as to introduce the essence of STEM education.

The assistant moderator presents the first film showing part of a class during which a group of preschool children is experimenting with milk-a classic example of milk painting. The children carefully drop in some food colouring onto milk (poured into a bowl) and tap it with a toothpick or a small stick dipped in a detergent. Surprised and fascinated, they observe chemical reactions taking place in the milk, which they see as mixing of colors (Link: https://www.youtube.com/watch?v=T-Oa-uHP_t0).

The assistant moderator presents the other film showing a preschool girl in the course of preparing a meal (salsa Bolognese) using Thermomix, with a little assistance from an adult person (Link: https://www.youtube.com/watch?v=me1DfTAqGWE).

\section{Discussion}

After the screenings, the moderator asks the following questions:

(a) What is your opinion about such classes/workshops?

(b) What are the aims of such classes/workshops? 
(c) What skills/abilities are developed in children who attend such classes?

(d) What is your personal experience of organising such classes with preschool children?

(e) What challenges/problems can such workshops generate?

(f) What do you think should be considered necessary to deliver such classes to preschool children?

\section{Definition of STEM is presented to the participants}

The term "STEM" refers to the process of integrated teaching and learning in the scope of natural sciences, technology, engineering (technical sciences) and maths. It includes educational activity at all levels of education (from nursery school to adult education) and takes place in both formal and informal classroom settings. The general aim of STEM is to further develop STEM literacy in society. STEM literacy means:

- developing knowledge, attitudes and skills in identifying questions and problems related to every-day situations, explaining the natural and man-made world, formulating evidence-based conclusions,

- understanding the characteristic features of STEM disciplines as manifestations of human knowledge, research and projects,

- promoting commitment to STEM-related problems and ideas of science, technology, engineering and mathematics.

STEM remains a relatively unknown concept in Poland, hence persons who planned the focus group assumed that the participants would not be familiar with the very notion or the elements of the STEM model. In order to avoid awkwardness resulting from lack of knowledge of the notion among the participants it was decided that STEM would be explicitly defined during the session.

The moderator introduces the definition of STEM (each participant also receives it printed) which is followed by a brief analysis of the notion; any issues that remain unclear are thoroughly explained. The moderator responds to questions asked by the students, if they have any.

\section{Discussion}

After presenting and discussing the definition of STEM the moderator asks the following questions:

(a) Is it possible to develop science-oriented thinking in preschool children? How?

(b) What would you need to develop such skills/abilities in preschool children? 


\section{Closing phase}

This part closes the discussion. It should essentially contain a summary of the discussion as well as acknowledgement of the participants' effort - their commitment as demonstrated during the session.

\section{Discussion is briefly summarized}

The moderator makes sure that the topic has been exhausted and all provided information has been properly understood. She then asks whether anyone would like to add, explain or further comment on any issues raised.

\section{Facilitators thank the participants for their time and participation}

The moderator and her assistant thank everyone for their participation in the discussion. The participants receive small gifts.

Once the study subjects have left the room, the moderator together with her assistant check the quality of the recording, summarise the most important ideas and clear the room. As soon as practicable, a transcript of the recording is made and analysed.

Table 1. Consolidated criteria for reporting qualitative studies (COREQ): 30-item checklist

\begin{tabular}{|c|c|c|}
\hline No. & Item & Guide question/description \\
\hline \multicolumn{3}{|r|}{ Domain 1: Research team and reflexivity } \\
\hline \multicolumn{3}{|r|}{ Personal Characteristics } \\
\hline 1. & $\begin{array}{l}\text { Interviewer/ } \\
\text { facilitator }\end{array}$ & $\begin{array}{l}\text { Which author/s conducted the interview or focus group? } \\
\text { The persons conducting the research were Irmina Rostek and Katarzyna } \\
\text { Szewczuk }\end{array}$ \\
\hline 2. & Credentials & $\begin{array}{l}\text { What were the researcher's credentials? (e.g., PhD, MD) } \\
\text { Persons conducting the research have an academic title: doctor of } \\
\text { psychological sciences, doctor of pedagogical sciences. }\end{array}$ \\
\hline 3. & Occupation & $\begin{array}{l}\text { What was their occupation at the time of the study? } \\
\text { The persons conducting the research are academic teachers employed at } \\
\text { Jesuit University Ignatianum in Krakow, Poland. }\end{array}$ \\
\hline 4. & Gender & $\begin{array}{l}\text { Was the researcher male or female? } \\
\text { The people conducting the study were women. }\end{array}$ \\
\hline 5. & $\begin{array}{l}\text { Experience and } \\
\text { training }\end{array}$ & $\begin{array}{l}\text { What experience or training did the researcher have? } \\
\text { They have experience in conducting classes with students and } \\
\text { participated in methodological workshops that dealt with the subject of } \\
\text { qualitative research. }\end{array}$ \\
\hline
\end{tabular}




\begin{tabular}{|c|c|c|}
\hline \multicolumn{3}{|r|}{ Relationship with participants } \\
\hline 6. & $\begin{array}{l}\text { Relationship } \\
\text { established }\end{array}$ & $\begin{array}{l}\text { Was a relationship established prior to study commencement? } \\
\text { The persons participating in the study knew the interviewers. }\end{array}$ \\
\hline 7. & $\begin{array}{l}\text { Participant } \\
\text { knowledge of the } \\
\text { interviewer }\end{array}$ & $\begin{array}{l}\text { What did the participants know about the researcher? } \\
\text { (e.g., personal goals, reasons for doing the research) } \\
\text { Some of the survey participants knew the moderators from previous } \\
\text { activities during the studies. All students also knew that the moderators } \\
\text { were taking part in the project "Kitchen Lab } 4 \text { Kids," and they knew the } \\
\text { purpose of the meeting and its reasons. }\end{array}$ \\
\hline 8. & $\begin{array}{l}\text { Interviewer } \\
\text { characteristics }\end{array}$ & $\begin{array}{l}\text { What characteristics were reported about the interviewer/facilitator? } \\
\text { (e.g., Bias, assumptions, reasons and interests in the research topic) } \\
\text { One moderator and her assistant were representatives of the Polish team } \\
\text { taking part in the international project called "Kitchen Lab for Kids." } \\
\text { A successful moderator should demonstrate specific competencies (traits), } \\
\text { both in terms of personality as well as research and leadership. }\end{array}$ \\
\hline \multicolumn{3}{|r|}{ Domain 2: Study design } \\
\hline \multicolumn{3}{|r|}{ Theoretical framework } \\
\hline 9. & $\begin{array}{l}\text { Methodological } \\
\text { orientation and } \\
\text { theory }\end{array}$ & $\begin{array}{c}\text { What methodological orientation was stated to underpin the } \\
\text { study? (e.g., grounded theory, discourse analysis, ethnography, } \\
\text { phenomenology, content analysis) } \\
\text { Conversational analysis }\end{array}$ \\
\hline \multicolumn{3}{|r|}{ Participant selection } \\
\hline 10. & Sampling & $\begin{array}{c}\text { How were participants selected? (e.g., purposive, convenience, } \\
\text { consecutive, snowball) } \\
\text { Members of the group were selected based on purposive sampling } \\
\text { according to a set of criteria predefined by the researcher and adjusted to } \\
\text { the specific nature of the project. }\end{array}$ \\
\hline 11. & $\begin{array}{l}\text { Method of } \\
\text { approach }\end{array}$ & $\begin{array}{l}\text { How were participants approached? } \\
\text { (e.g., face-to-face, telephone, mail, e-mail) } \\
\text { The participants were recruited for the study by e-mail, as well as } \\
\text { through conversations and information about the project - these were } \\
\text { face-to-face conversations. }\end{array}$ \\
\hline 12. & Sample size & $\begin{array}{l}\text { How many participants were in the study? } \\
\text { The focus group interview was conducted in a small (8 persons), } \\
\text { non-random group. }\end{array}$ \\
\hline 13. & Non-participation & $\begin{array}{l}\text { How many people refused to participate or dropped out? Reasons? } \\
\text { Two people withdrew from the study. The reasons are unknown. }\end{array}$ \\
\hline \multicolumn{3}{|r|}{ Setting } \\
\hline 14. & $\begin{array}{l}\text { Setting of data } \\
\text { collection }\end{array}$ & $\begin{array}{l}\text { Where was the data collected? (e.g., home, clinic, workplace) } \\
\text { The focus interview was conducted at the Jesuit University Ignatianum } \\
\text { in Krakow, Poland. One of the lecture halls was arranged for the } \\
\text { research. This is the primary workplace for moderators. }\end{array}$ \\
\hline
\end{tabular}




\begin{tabular}{|c|c|c|}
\hline 15. & $\begin{array}{c}\text { Presence of } \\
\text { non-participants }\end{array}$ & $\begin{array}{l}\text { Was anyone else present besides the participants and researchers? } \\
\text { No. Only } 8 \text { students, moderator and assistant. }\end{array}$ \\
\hline 16. & $\begin{array}{l}\text { Description of } \\
\text { sample }\end{array}$ & $\begin{array}{c}\text { What are the important characteristics of the sample? } \\
\text { (e.g., demographic data, date) } \\
\text { Group membership was relatively homogenic. The study involved } \\
\text { students of teacher training programs, mainly in preschool teaching and } \\
\text { early school education. }\end{array}$ \\
\hline \multicolumn{3}{|r|}{ Data collection } \\
\hline 17. & Interview guide & $\begin{array}{l}\text { Were questions, prompts, guides provided by the authors? } \\
\text { Was it pilot tested? } \\
\text { The focus meeting was conducted according to the scenario (the exact } \\
\text { course can be found in the appendix). No pilot tests were undertaken, } \\
\text { but due to the implementation of the research in } 4 \text { countries, it was } \\
\text { discussed in detail and analyzed with partners. International team } \\
\text { participating in the project (representatives). }\end{array}$ \\
\hline 18. & Repeat interviews & $\begin{array}{l}\text { Were repeat interviews carried out? If yes, how many? } \\
\text { No (but the same interviews were conducted in all countries). }\end{array}$ \\
\hline 19. & $\begin{array}{l}\text { Audio/visual } \\
\text { recording }\end{array}$ & $\begin{array}{l}\text { Did the research use audio or visual recording to collect the data? } \\
\text { Sound (audio) recordings were used in the study. Participants' statements } \\
\text { were recorded using two dictaphones. }\end{array}$ \\
\hline 20. & Field notes & $\begin{array}{l}\text { Were field notes made during and/or after the interview or focus } \\
\text { group? } \\
\text { Field notes were made by the assistant during the meeting. }\end{array}$ \\
\hline 21. & Duration & $\begin{array}{c}\text { What was the duration of the interviews or focus group? } \\
\text { The meeting lasted } 1.5 \text { hours. }\end{array}$ \\
\hline 22. & Data saturation & $\begin{array}{l}\text { Was data saturation discussed? } \\
\text { Yes. }\end{array}$ \\
\hline 23. & $\begin{array}{l}\text { Transcripts } \\
\text { returned }\end{array}$ & $\begin{array}{l}\text { Were transcripts returned to participants for comment and/or } \\
\text { correction? } \\
\text { The transcript was not shown to the meeting participants. }\end{array}$ \\
\hline \multicolumn{3}{|r|}{ Domain 3: Analysis and finding } \\
\hline \multicolumn{3}{|r|}{ Data analysis } \\
\hline 24. & $\begin{array}{l}\text { Number of data } \\
\text { coders }\end{array}$ & $\begin{array}{l}\text { How many data coders coded the data? } \\
\text { The moderators coded the data. Several thematic categories were } \\
\text { distinguished according to the adopted research questions. }\end{array}$ \\
\hline 25. & $\begin{array}{l}\text { Derivation of } \\
\text { themes }\end{array}$ & $\begin{array}{l}\text { Were themes identified in advance or derived from the data? } \\
\text { The topics were identified in advance because they were written in the } \\
\text { script (as questions). }\end{array}$ \\
\hline 26. & $\begin{array}{l}\text { Participant } \\
\text { checking }\end{array}$ & $\begin{array}{l}\text { Did participants provide feedback on the findings? } \\
\text { The results of the study were made available to interested persons. }\end{array}$ \\
\hline
\end{tabular}




\begin{tabular}{|c|c|c|}
\hline \multicolumn{2}{|c|}{ Reporting } \\
\hline 27. & $\begin{array}{c}\text { Quotations } \\
\text { presented }\end{array}$ & $\begin{array}{c}\text { Were participant quotations presented to illustrate the themes/ } \\
\text { findings? Was each quotation identified? (e.g., participant number) } \\
\text { In order to illustrate the topics, selected quotes from the meeting } \\
\text { participants were quoted. }\end{array}$ \\
\hline 28. & $\begin{array}{c}\text { Data and findings } \\
\text { consistent }\end{array}$ & $\begin{array}{c}\text { Was there consistency between the data presented and the findings? } \\
\text { Yes. }\end{array}$ \\
\hline 29. & $\begin{array}{c}\text { Clarity of major } \\
\text { themes }\end{array}$ & $\begin{array}{c}\text { Wes, the main topics were separated in the analysis of the materials from } \\
\text { focus interviews. }\end{array}$ \\
\hline 30. & $\begin{array}{c}\text { Clarity of minor } \\
\text { themes }\end{array}$ & Is there a description of diverse cases or discussion of minor themes? \\
Yes.
\end{tabular}

\section{ADDRESS FOR CORRESPONDENCE}

Martyna Szczotka

Jesuit University Ignatianum in Krakow e-mail: martyna.szczotka@ignatianum.edu.pl

Katarzyna Szewczuk

Jesuit University Ignatianum in Krakow e-mail: katarzyna.szewczuk@ignatianum.edu.pl 